\title{
Modulation of Post-Coital Dopaminergic Tone by Prior Parity
}

\author{
Lucia Helena Sider ${ }^{1,2^{*}}$, Erica Engelberg Teixeira da Silva Hucke ${ }^{1,3}$ and Luciano Freitas \\ Felicio $^{1}$ \\ ${ }^{1}$ Departamento de Patologia; Faculdade de Medicina Veterinária e Zootecnia; Universidade de São Paulo; São \\ Paulo - SP - Brasil. ${ }^{2}$ Empresa Brasileira de Pesquisa Agropecuária - Embrapa Caprinos e Ovinos; Estrada Sobral- \\ Groaíras, km 4; Zona Rural; 62010-970; Sobral - CE - Brasil. ${ }^{3}$ Centro Universitário da Fundação de Ensino \\ Octávio Bastos; São João da Boa Vista - SP - Brasil
}

\begin{abstract}
The aim of this study was to investigate the possible effects of reproductive experience on dopaminergic profile in three different brain tissues, hypothalamus, striatum and cortex in rats on $7^{\text {th }}$ - $8^{\text {th }}$ day of pregnancy during the lightdark shift (between 1700-1900h). Results showed that in hypothalamus, dopamine levels increased and DOPAC/DA decreased as a function of parity. In cortex, no differences were observed. In striata, the haloperidol-induced HVA and HVA/DA increases were less intense in experienced animals. These findings suggested that reproductive experience produced functional central changes during pregnancy, with different neurochemical responses depending on the brain region.
\end{abstract}

Key words: hypothalamus, striatum, cortex, haloperidol, HVA and DOPAC

\section{INTRODUCTION}

Reproductive experience affects a series of reproductive performance parameters, such as calving rate (Buttram and Willham, 1989), litter size in dogs (Gavrilovic et al., 2008), weaning-toestrous interval in sows (Santos et al, 2006) and cattle (Melendez et al., 2008), lactation length and milk yield in cattle (Parra-Bracamonte et al., 2005). Reproductive experience also affects endocrine, neurochemical and behavioral responses. Dopaminergic systems have a key role in all of these three aspects. In regards to the endocrine system, dopamine is the major inhibitory factor of prolactin (PRL) secretion and release (Ben-Jonathan et al., 1985). In non- pregnant women (Musey et al., 1987a and b) and rats (Bridges and Byrnes, 2006; Byrnes and Bridges, 2006; Byrnes et al., 2001; CarvalhoFreitas et al., 2007; Kinsley, 1994; Kinsley and Bridges, 1988; Mann and Bridges, 1992; Mann et al., 1989), reproductive experience reduces PRL secretion. A similar effect is observed in early pregnancy in rats where a prior parity inhibited both diurnal and nocturnal PRL surges (Sider et al., 2003; Bridges et al. 1993). During lactation, multiparous females have attenuated sucklinginduced PRL secretion compared to primiparous females (Mann and Bridges, 1992). Reproductive experience also reduces the sensitivity of nonlactating women to the PRL-releasing actions of dopamine antagonist, metoclopramide (Del los

*Author for correspondence: sider@cnpc.embrapa.br 
Monteros, 1991). The same effect is demonstrated in rats after haloperidol injection (Bridges et al., 1997). These findings have demonstrated that the reproductive experience alters the female's sensitivity to a dopamine antagonist in regulating PRL secretion.

In addition to its role in endocrine mechanisms, dopamine has importance in motor activity and some well-known pathological conditions, such as schizophrenia (Howes et al., 2009), Parkinson (Soriano Castrejon et al., 2005) and Huntington diseases (Charvin et al., 2008). In addition, dopamine has also an important role in the physiological processes that involve cognition (Schultz et al., 1997).

The reproductive experience modulates a variety of central parameters including the dopaminergic system functions. Felicio et al (1996) showed that dopamine was increased in both the hypothalamus and striatum of $7^{\text {th }}-8^{\text {th }}$-day pregnant rats decapitated between 1200-1400 h. Further investigations demonstrated the same effect in the hypothalamus of rats killed between 1700-1900 h (Sider et al, 2003). In the striatum, the haloperidolinduced increase in dopaminergic metabolites is reduced by the reproductive experience. This phenomenon is observed in both ex vivo homogenates of multigravid compared to primigravid rats (Felicio et al., 1996) and in vivo in primiparous compared to nulliparous rats submitted to microdyalisis in this region. The reproductive experience influence is seen also in the patterns in anticipation and response to daily changes in light/dark cycle in striatal dopaminergic terminals of primiparous rats compared to nulliparous rats submitted to microdyalisis (Hucke et al., 1998). These results indicate an influence of reproductive experience on cognitive functions.

Dopamine-related behavioral responses are also affected by the reproductive experience, and these phenomena vary according to brain region. Apomorphine-induced stereotypy is significantly higher in primiparous compared to nulliparous rats (Byrnes et al., 2001; Hucke et al, 2001), while apomorphine-induced hypothermia does not differ between the groups, suggesting that the sensitivity of dopaminergic terminals in striatum are affected, while the sensitivity of hypothalamic terminals may not be modulated by the reproductive experience (Hucke et al., 2001). Studies with prepulse inhibition also demonstrate that forebrain dopamine receptors are more sensitive in the females that have experienced pregnancy and lactation as compared to virgin females (Byrnes et al. 2001; Byrnes et al., 2007). Pre-synaptic mechanisms seem not to be altered as a function of reproductive experience, as suggested by the failure to demonstrate any reproductive experience-induced differences in the stereotypic behavior responses induced by the indirect dopamine agonist amphetamine (Hucke et al., 2001). In addition to the previously mentioned drugs, dopamine is also involved in the mechanisms of action of toxic plants (Schwarz et al., 2005 and 2007).

In spite of data accumulated on the reproductive experience modulation dopaminergic transmission in hypothalamus and striatum, little is known about a possible modulation of reproductive experience in the cortical dopaminergic system. In the present work, investigations were made on the influence of reproductive experience on the central levels of dopamine and its metabolites in brain tissues, such as the hypothalamus, cortex and striata, in the rats during the light/dark shift (1700$1900 \mathrm{~h}$ ). These tissues were chosen for containing the terminals from all the three dopaminergic systems, namely hypothalamic, meso-cortic-limbic and nigrostriatal pathways. Dopamine receptors in these areas are subject to the action of drugs. In order to assess reproductive experience influence on dopamine related drug effects, a set of rats was challenged with the dopamine antagonist haloperidol.

\section{MATERIALS AND METHODS}

\section{Subjects}

Forty-six female Wistar rats $(80 \pm 10$ days old at the beginning of the experiment) were individually housed in polypropylene cages $(45 \times 25 \times 20 \mathrm{~cm})$ in a controlled light-dark cycle (lights on from 0600$1800 \mathrm{~h}$ ). Water and food were available ad libitum. Rats were randomly assigned to one of two groups. Initially, one set of rats was mated to the males. After mating, the pregnant females were again individually housed and allowed to give birth. Their neonates were culled to six pups (three males and three females) on the day after the parturition, and these dams raised their litters until the weaning on day 21 postpartum. The second group of the females remained unmated for the same period of time. Approximately 2-3 weeks after the weaning, pups from the first set of 
animals, both experienced and inexperienced females, were time-mated to the males, thereby generating two age-matched groups of pregnant rats: one multigravid (second pregnancy) and the other primigravid (first pregnancy). The day in which the sperm was observed in the vaginal lavage of each female was designated as day 1 of pregnancy. The animals used in this study were maintained in accordance with the guidelines of the Committee on Care and Use of Laboratory Animal Resources, National Research Council, USA.

\section{Treatment}

On the $7^{\text {th }}-8^{\text {th }}$ day of pregnancy, animals were treated intraperitoneally (IP) with saline or haloperidol $(1 \mathrm{mg} / \mathrm{Kg})$ and 30 minutes later were decapitated between 1700 and $1900 \mathrm{~h}$. This haloperidol dose was chosen because it produces an effect but was still unable to sedate the animals. After 30 min of injection, it showed its maximum effect. The rationale for choosing $1700-1900 \mathrm{~h}$ as the time of collection of tissues and blood was that this period contained the light-dark shift and this could reveal phenomena related to stress responses to the beginning of active period in rats. In addition, this time was thought to be part of diurnal PRL surge during early pregnancy.

After decapitation, the skull and underlying meninges were removed. Brains were dissected on a frozen plate surrounded by dry ice. Hypothalamus was dissected as described by Carvalho-Freitas et al. (2007). After the removal of olfactory bulbs, brains were cut on the coronal plane to separate the frontal portion of cortex from other brain structures. In order to remove the striatum, first the left and right hemispheres were separated and then the lateral ventricles were opened to expose the striata, which were dissected on both sides of the brain. Tissues were weighed and immediately stored in liquid nitrogen. Pregnancy was confirmed at sacrifice and the number of implantation sites was recorded for each animal.

\section{Neurochemistry}

Tissues were homogenized in perchloric acid by sonication and dopamine (DA) and their metabolites, homovanillic acid (HVA) and 3,4dihydroxyphenilacetic acid (DOPAC), were measured by high-performance liquid chromatography with an electrochemical detector
(HPLC-ED). Monoamines were measured using an HPLC system (model 6A; Shimadzu, Kyoto, Japan) with a C-18 column (Shimpak; ODS, Kyoto, Japan), an electrochemical detector (model 6A; Shimadzu), a sample injector (valve for 20 $\mu \mathrm{l}$ ), and an integrator (model 6A Chromatopac; Shimadzu). The limit of detection was $0.02 \mathrm{ng}$ for DA, DOPAC, and HVA. Turnover of DA was expressed as the DOPAC/DA and HVA/DA. The haloperidol-induced response was calculated by dividing the individual value of the animal treated by haloperidol by the mean of the respective saline-treated animals multiplied by $100 \%$.

\section{Statistics}

Neurochemical data were initially submitted to Bartlett's preliminary test. Since most of the data were shown to be parametric, they were analyzed using a One-Way ANOVA followed by Tukey's post-test. Non-parametric data were analyzed by Kruskal-Wallis test with Dunn's post-test. Differences were considered significant at $\mathrm{p} \leq 0.05$. Haloperidol-induced response was calculated by Student $t$ test. This test was also used to compare the reproductive parameters. No differences were found in the numbers of implantation sites, reabsorption and right/left side implantation among groups (data not shown).

\section{RESULTS AND DISCUSSION}

The activity of dopaminergic system is modulated by the reproductive experience. The findings of the present study demonstrated that a single previous parity increased the dopamine concentrations $(\mathrm{P}<0.05)$ and reduced the dopaminergic turnover in the hypothalamus of saline treated animals $(\mathrm{P}<0.05$; Table 1$)$. This could be due to a functional adjustment reflecting a diminished pre-synaptic activity, perhaps allowing an accumulation of dopamine in the vesicles. Possibly such a decrease in the hypothalamic dopaminergic terminal activity was mild enough to be revealed only by a significant drop in DOPAC/DA ratio with no influence on the HVA/DA ratio (Table 1). A well-established technique used to understand the functions and dysfunctions of a neurotransmitter has been to measure the enzymatic metabolites of that molecule. Dopamine is no exception. Combined measurements of DOPAC and dopamine have 
been used to assess the activity of dopaminergic neurons. This combination provides additional information than either parameter alone. DOPAC may be more closely related to presynaptic dopamine levels while dopamine and, similarly, HVA levels are related to the rate of neuron signaling. Together dopamine and DOPAC and HVA measurement may provide insight regarding the rate of dopamine turnover.

No effect of reproductive experience was revealed in striatal dopaminergic parameters concerning haloperidol-induced response (data not shown).

Table 1 - Hypothalamic dopamine and its metabolite levels (ng/g tissue) and turnover of primi and multigravid rats treated with saline or haloperidol $(1 \mathrm{mg} / \mathrm{Kg})$.

\begin{tabular}{lcccc}
\hline & Primi Sal $(\mathbf{N}=6)$ & Primi Halo $(\mathbf{N}=6)$ & Multi Sal $(\mathbf{N}=7)$ & Multi Halo $(\mathbf{N}=8)$ \\
\hline DA & $200.5 \pm 37.6$ & $231.3 \pm 27.6$ & $323.0 \pm 24.9 *$ & $281.3 \pm 29.7$ \\
HVA & $6.3 \pm 0.99$ & $8.83 \pm 0.80$ & $6.78 \pm 1.22$ & $7.91 \pm 0.96$ \\
DOPAC & $97.5 \pm 26.0$ & $105.1 \pm 14.1$ & $84.2 \pm 5.0$ & $91.8 \pm 13.2$ \\
HVA/DA & $0.038 \pm 0.007$ & $0.034 \pm 0.002$ & $0.022 \pm 0.004$ & $0.025 \pm 0.002$ \\
DOPAC/DA & $0.47 \pm 0.07$ & $0.45 \pm 0.02$ & $0.27 \pm 0.02 *$ & $0.32 \pm 0.03$ \\
\hline
\end{tabular}

Data are expressed as mean \pm SE.

$* \mathrm{P} \leq 0.05$ compared to the primigravid saline group.

There were no significant differences related to the reproductive experience in basal concentrations dopamine and its metabolites in the cortex of animals treated with saline or haloperidol (Table 2). Haloperidol-induced responses did not differ between the primi and multigravid animals either (data not shown). This could be due to a lack of reproductive experience-induced effect on cortical dopaminergic transmission.

Table 2 - Cortical dopamine and its metabolite levels (ng/g tissue) and turnover of primi and multigravid rats treated with saline or haloperidol $(1 \mathrm{mg} / \mathrm{Kg})$.

\begin{tabular}{lcccc}
\hline & Primi Sal $(\mathbf{N}=6)$ & Primi Halo $(\mathbf{N}=6)$ & Multi Sal $(\mathbf{N}=7)$ & Multi Halo $(\mathbf{N}=8)$ \\
\hline DA & $119.4 \pm 8.4$ & $112.4 \pm 1.4$ & $124.9 \pm 7.0$ & $128.3 \pm 5.5$ \\
HVA & $8.5 \pm 1.9$ & $12.0 \pm 2.4$ & $8.7 \pm 1.4$ & $10.2 \pm 1.8$ \\
DOPAC & $35.8 \pm 8.9$ & $50.6 \pm 8.8$ & $41.5 \pm 5.2$ & $51.4 \pm 6.8$ \\
HVA/DA & $0.072 \pm 0.013$ & $0.103 \pm 0.026$ & $0.060 \pm 0.006$ & $0.066 \pm 0.014$ \\
DOPAC/DA & $0.29 \pm 0.06$ & $0.39 \pm 0.06$ & $0.33 \pm 0.05$ & $0.40 \pm 0.05$ \\
\hline
\end{tabular}

Data expressed as mean \pm SE.

Haloperidol induces significant augmentation in the striatal levels of metabolites and turnover. Dopaminergic system parameters did not significantly differ between the primi and multigravid subjects treated with either saline or haloperidol (Table 3). Nevertheless, haloperidolinduced increase in HVA striatal levels $(\mathrm{P}<0.01)$ and dopaminergic turnover (HVA/DA; $\mathrm{P}<0.05)$ were less intense in the experienced animals (Fig. $1 \mathrm{~B}$ and $\mathrm{D}$, respectively). These data confirmed and expanded the notion that the reproductive experience modulated the dopaminergic tone (Bridges et al., 1993; Felicio et al., 1996; Bridges et al., 1997; Hucke et al., 1998, 2001; Byrnes et al., 2001; Sider et al., 2003; Byrnes and Bridges, 2007). A similar effect was observed in DA response to haloperidol, although the drug was not supposed to produce an increase in DA levels $(\mathrm{P}<0.05$; Fig. $1 \mathrm{~A})$.

Importantly, the modulatory effects induced by a previous reproductive experience seemed to vary according to the brain area. Although some changes observed in one area were not detected in the other, the parameters measured never varied in opposite respects from one brain region to another. This might imply that the effects of reproductive experience on dopaminergic function could have quantitative but not qualitative dissimilarities according to the area of the brain.

A previous study described increased hypothalamic and striatal dopamine concentrations in $7^{\text {th }}$-day multigravid rats killed between 1200 $1400 \mathrm{~h}$ (Felicio et al., 1996). These findings were partially consistent with those reported here in 
which similar changes were found in the hypothalamus but not in the striatum. In this case, the reproductive experience-induced effects on dopaminergic systems were observed in the pregnant animals during a light-dark shift phase. In the present study, haloperidol injection was done 30 minutes before the decapitation, differing from the previous study in which a 1-h interval was used. Since the time of the day the animals were decapitated was different in each study, the differences could suggest that the reproductive experience-induced changes in the hypothalamic dopamine might be independent of the time of the day, while the reproductive experience-induced changes in the striatal dopamine expressed according to the time of the day. In fact, it has been demonstrated that both the time of the day and a previous reproductive experience induced changes in the dopamine related neurochemical profile (Sider et al., 2003).

Table 3 - Striatal dopamine and its metabolite levels (ng/g tissue) and turnover of primi and multigravid rats treated with saline or haloperidol $(1 \mathrm{mg} / \mathrm{Kg})$.

\begin{tabular}{lcccc}
\hline & Primi Sal $(\mathbf{n}=6)$ & Primi Halo $(\mathbf{n}=6)$ & Multi Sal $(\mathbf{n}=7)$ & Multi Halo $(\mathbf{n}=8)$ \\
\hline DA & $6201 \pm 664$ & $7890 \pm 345$ & $7154 \pm 616$ & $7524 \pm 492$ \\
HVA & $167 \pm 14$ & $513 \pm 28 * * *$ & $213 \pm 13$ & $422 \pm 58$ \\
DOPAC & $1899 \pm 188$ & $4581 \pm 433 * * *$ & $2219 \pm 260$ & $3904 \pm 480 *$ \\
HVA/DA & $0.027 \pm 0.001$ & $0.066 \pm 0.005 * *$ & $0.030 \pm 0.004$ & $0.056 \pm 0.005$ \\
DOPAC/DA & $0.31 \pm 0.02$ & $0.58 \pm 0.05 * * *$ & $0.31 \pm 0.03$ & $0.51 \pm 0.03 * *$ \\
\hline
\end{tabular}

Data expressed as mean \pm SE.

$* \mathrm{P} \leq 0.05$, ** $\mathrm{P} \leq 0.01$, compared to the respective saline group.
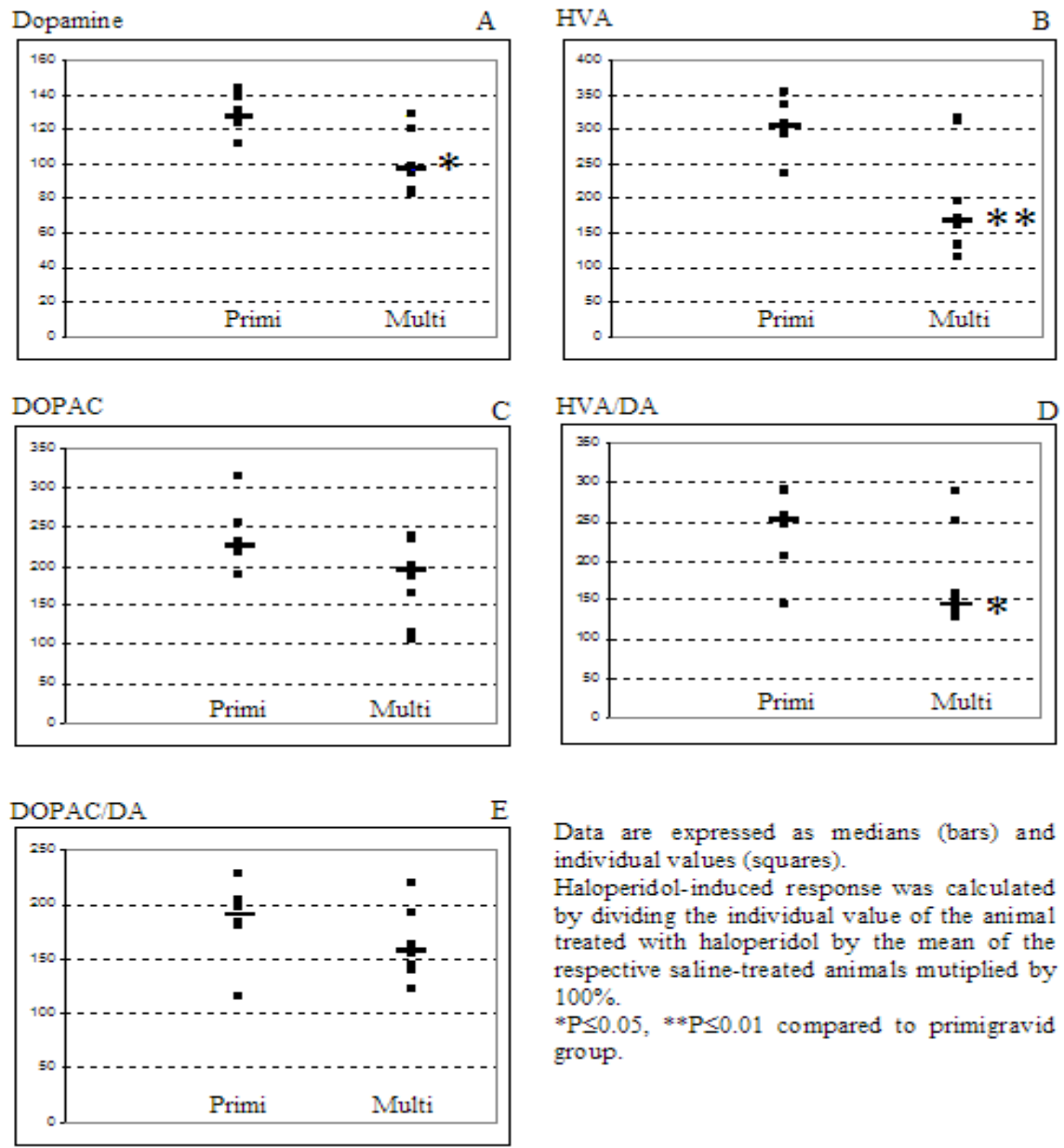

Data are expressed as medians (bars) and individual values (squares).

Haloperidol-induced response was calculated by dividing the individual value of the animal treated with haloperidol by the mean of the respective saline-treated animals mutiplied by $100 \%$.

$* \mathrm{P} \leq 0.05,{ }^{*} \mathrm{P} \leq 0.01$ compared to primigravid group.

Figure 1 - Haloperidol-induced changes (percent change) in dopaminergic parameters of primigravid and multigravid rats. 
As previously demonstrated, the time of the day also influenced the striatal dopaminergic activity (Hucke et al., 1998; Nasello et al., 2003). The time of decapitation was interestingly chosen to coincide with the light-dark shift. The neurochemical responses at this time seemed to be influenced by the reproductive experience. Virgins showed an in vivo increase in the dopamine striatal turnover, starting before the light-dark shift, by anticipating the release of striatal dopamine before the lights were turned off, whereas this was not observed in the experienced cycling rats (Hucke et al., 1998). Haloperidol effects on striatum have been shown to display its maximum in vivo effects in 60 minutes compared roughly to 30 minute ex-vivo effects (Hucke et al., 1998).

Ex vivo dopamine hypothalamic levels are the sum of the concentrations of this neurotransmitter present in the pre-synaptic vesicles found in the synaptic cleft in various nuclei. The metabolite/dopamine ratios are better measures of dopaminergic system activity. These ratios are decreased in the hypothalamus of multigravid females. In this manner, the higher hypothalamic dopamine levels could be due to its accumulation in vesicles and/or to a lower rate of metabolization.

The influence of reproductive experience on the sensitivity to drugs is a striking point. In the striatum, there were significant differences in the haloperidol-induced response according to the reproductive experience. This non-specific dopaminergic antagonist induces a compensatory increase in dopamine metabolite, HVA levels that are a consequence of an increase in turnover ratios. Haloperidol blocks the post-synaptic dopamine receptors and induces a compensatory increase in dopamine release by pre-synaptic terminals. Consequently, the dopamine metabolization increases. This leads to the production of the dopamine final metabolite HVA that is present in the synaptic cleft. However, this increase in the metabolite levels and turnover is less evident in the multigravid as opposed to primigravid animals. This phenomenon is also observed in the striatal homogenates of multigravid as compared to primigravid rats killed at a different time of the day (Felicio et al., 1996) and in primiparous as opposed to nuliparous rats submitted to microdialysis in this brain region (Hucke et al., 1998). These data may suggest that reproductive experience lead the dopaminergic systems to present less intense responses, implied perhaps as a consequence of an increase in stability.

In addition to these observations on the striatal dopaminergic system, Bridges et al. (1997) showed that the haloperidol-induced prolactin secretion was less intense in primiparous than in the nuliparous rats. Furthermore, a prior reproductive experience reduces the sensitivity of non-nursing women to the endocrine action of metochlorpramide (Del los Monteros, 1991), another dopamine antagonist that induces the prolactin secretion. This modulation suggests a differentiated response of dopamine receptors in both the striatum and anterior pituitary.

Other neurons are also modulated by the reproductive experience. Multiparous are less sensitive than the primiparous rats to the opioidergic inhibition of maternal behavior (Mann and Bridges, 1992; Kinsley and Bridges, 1988), analgesia (Kinsley and Bridges, 1988) and prolactin secretion, induced by suckling stimulus (Mann and Bridges, 1992). Therefore, the reproductive experience probably changes several neuroendocrine systems in a possibly permanent manner and its effects may remain for the rest of adult life.

Other differences due to a previous reproductive experience in the females in physiological and cognitive aspects may exist (Kinsley et al., 1999). Dopamine receptors in different brain areas may be altered in number and affinity to endogenous and exogenous ligands. It is known that the pregnancy increases the number of dendritic spine numbers in some brain areas in the rodents, possibly generating cognitive improvements (Kinsley et al., 1999). Other brain modifications were reported in the cortex (Xerri et al., 1994), hyppocampus (Kinsley et al., 2006; Lambert et al., 2005) and amygdala (Lambert et al., 2005) as a function of RE. This raises a question as to whether these modulations could have a permanent or cumulative effect or even vary according to the interval between two or more pregnancies. The concept of reproductive experience includes all the social and hormonal events undergone since mating, pregnancy, delivery of neonates, lactation and maternal care to weaning. Further investigation is required to elucidate the involvement of individual aspects of the reproductive experience in the endocrine, neurochemical and behavioral DA-related responses. Results from the present work and others showed that the future studies focused on 
the behavior of DA receptors would be necessary to elucidate the participation of different subtypes in RE modulation of different tissues.

\section{CONCLUSION}

Results suggested that RE produced functional central changes during the pregnancy, with different neurochemical responses depending on the brain region. In hypothalamus, RE induced the changes in dopamine levels and turnover. Nevertheless, the striatal and cortical DA and metabolite levels remained unaltered. In striatum, the experienced animals showed a less intense augmentation in metabolite levels and turnover as a result of haloperidol administration.

\section{ACKNOWLEGMENTS}

This study was supported by the grants from the Fundação de Amparo à Pesquisa do Estado de São Paulo (FAPESP, \#01/00143-9) and Conselho Nacional de Desenvolvimento Científico e Tecnológico (CNPq, \#351107/92-4 awarded to LFF. LHS was supported by the Fundação de Amparo à Pesquisa do Estado de São Paulo (FAPESP, Proc. No. 97/11504-5).

\section{RESUMO}

A dopamina age nos níveis endócrino, neuroquímico e comportamental. A experiência reprodutiva modula alguns destes aspectos: a dopamina está aumentada no estriato e no hipotálamo de ratas muiltigrávidas entre 12:0014:00 horas. A sensibilidade dos terminais dopaminérgicos também parece ser modulada por uma experiência reprodutiva prévia. Nosso objetivo foi o de investigar os possíveis efeitos da experiência reprodutiva no perfil dopaminérgico de três diferentes tecidos cerebrais, hipotálamo, estriato e córtex em ratas no $7^{\circ}-8^{\circ}$ dia de gestação durante a fase de virada do ciclo claro-escuro (entre 17:00-19:00h). Nossos resultados mostraram que os níveis dopaminérgicos no hipotálamo aumentaram e o índice DOPAC/DA diminuiu em multigrávidas quando comparadas às primigrávidas. No córtex, nenhuma diferença foi encontrada. No estriato, o aumento de HVA e HVA/DA induzidos pelo haloperidol foi menos intenso nos animais experientes. Nossos resultados sugerem que a experiência reprodutiva produz alterações funcionais centrais durante a gestação, com diferentes respostas neuroquímicas de acordo com a região cerebral.

\section{REFERENCES}

Ben-Jonathan, N. (1985), Dopamine: a prolactininhibiting hormone. Endocrine Rev., 6, 564-589.

Bridges, R.S., Byrnes, E.M. (2006), Reproductive experience reduces circulating $17 \mathrm{~b}$-estradiol and prolactin levels during proestrus and alters estrogen sensitivity in female rats. Endocrinology, 147, 25752582.

Bridges, R.S., Felicio, L.F., Pellerin, L.J., Stuer, A.M., Mann, P.E. (1993), Prior parity reduces post-coital diurnal and nocturnal prolactin surges in rats. Life Sci., 53, 439-445.

Bridges, R.S., Henriquez, B.M., Sturgis, J.D., Mann, P.E. (1997), Reproductive experience reduces haloperidol-induced prolactin secretion in female rats. Neuroendocrinology, 66, 321-326.

Buttram, S.T.; Willham, R.L. (1989), Size and management effects on reproduction in first-, secondand third-parity beef cows. J. Anim. Sci., 67, 21912196.

Byrnes, E.M., Byrnes, J.J., Bridges, R.S. (2001), Increased sensitivity of dopamine systems following reproductive experience in rats. Pharmacol. Biochem. Beh., 68, 481-489.

Byrnes, E.M., Bridges, R.S. (2006), Reproductive experience alters anxiety-like behavior in the female rat. Horm. Beh., 50, 70-76.

Byrnes, E.M., Bridges, R.S., Scantan, V.F., Babb, J.A., Byrnes, J.J. (2007), Sensorimotor gating and dopamine function in postpartum rats. Neuropsychopharmacology, 32, 1021-1031.

Byrnes EM, Bridges RS. (2007), Reproductive experience and expression of dopamine $\mathrm{D}(2)$ receptor mRNA: a possible mechanism for reduced prolactin secretion in primiparous rats. J Neuroendocrinol. 19, 773-8.

Carvalho-Freitas ,M.I.R., Anselmo-Franci, J.Á., Teodorov, E., Nasello, A.G., Palermo-Neto, J., Felicio, L.F. (2007), Reproductive experience modifies dopaminergic function, serum levels of prolactin, and macrophage activity in female rats. Life Sci., 81, 128-136.

Charvin, D.; Roze, E.; Perrin, V.; Deyts, C.; Betuing, S.; Pages, C.; Regulier, E.; Lushi-Carter, R.; Brouillet, E.; Deglon, N.; Caboche, J. (2008), Haloperidol protects striatal neurons from dysfunction induced by mutant huntingtin in vivo. Neurobiol. Disease, 29, 22-29. 
Del los Montero, E., Cornejo, J., Parra, A. (1991), Differential prolactin response to oral metoclopramide in nulliparous versus parous women throughout the menstrual cycle. Fertil. Steril., 55, 885-889.

Felicio, L.F., Florio, J.C., Sider, L.H., Cruz-Casallas, P.E., Bridges, R.S. (1996), Reproductive experience increases striatal and hypothalamic dopamine levels in pregnant rats. Brain Res. Bull., 40, 253-256.

Gavrilovic, B.B.; Andersson, K.; Forsberg, C.L. (2008), Reproductive pattern in the domestic dog - A retrospective study of the Drever breed. Theriogenology, 70, 783-794.

Howes, O.D.; Montgomery, A.J.; Asselin, M.C.; Murray, R.M.; Valli, I.; Tabraham, P.; BramonBosch, E.; Valmaggia, L.; Johns, L.; Broome, M.; McGuire, P.K.; Grasby, P.M. (2009) Elevated striatal dopamine function linked to prodromal signs of schizophrenia. Arch. Gen. Psychiatry, 66, 13-20.

Hucke, E.E., Cruz-Casallas, P.E., Florio, J.C., Felicio, L.F., Bridges, R.S. (1998), Reproductive experience reduces striatal dopaminergic responses in freely moving female rats. Neuroreport, 9, 3589-3593.

Hucke, E.E., Cruz-Casallas, P.E., Sider, L.H., Felicio, L.F. (2001), Reproductive experience modulates dopamine-related behavioral responses. Pharmacol. Biochem. Behav., 68, 575-582.

Kinsley, C.H., Bridges, R.S. (1988), Parity-associated reductions in behavioral sensitivity to opiates. Biol. Reprod., 39, 270-278.

Kinsley, C.H. (1994), Developmental psychobiological influences on rodent parental behavior. Neurosci. Biobehav. Rev., 18, 269-280.

Kinsley, C.H., Madonia, L., Gifford, G.W., Tureski, K., Griffin, G.R., Lowry, C., Williams, J., Collins, J., McLearie, H., Lambert, K.G. (1999), Motherhood improves learning and memory. Nature, 402, 137138.

Kinsley, C.H.; Trainer, R.; Stafisso-Sandoz, G.; Quadros, P.; Marcus, L.K.; Hearon, C.; Meyer, E.A.,A.; Hester, N.; Morgan, M.; Kozub, F.J.; Lambert, K.G. (2006), Motherhood and the hormones of pregnancy modify concentrations of hippocampal neuronal dendritic spines. Horm.Beh., 49, 131-142.

Lambert, K.G.; Love, G.; Stevens, L.; Klein, S.l.; Conway, A.F.; Kinsley, C.H. (2005), Nissl analysis indicate maternal-induced hippocampal and amygdalar neuronal/glia plasticity in wild caught Norqay rats. Poster presented at the Annual Meeting of the Society for Neuroscience, Washington DC.

Mann, P.E., Kinsley, C.H., Ronsheim, P.M., Bridges, R.S. (1989), Long-term effects of parity on opioid and nonopioid behavioral and endocrine respondes. Pharmacol. Biochem. Behav., 34, 83-88.

Mann, P.E., Bridges, R.S. (1992), Neural and endocrine sensitivities to opioids decline as a function of multiparity in the rat. Brain. Res., 580, 241-248.
Melendez, P.; Duchens, M.; Perez, A.; Moraga, L.; Archbald, L. (2008), Characterization of estrus detection, conception and pregnancy risk of Holstein cattle from the central area of Chile. Theriogenology, 70, 631-637.

Musey, V.C., Collins, D.C., Musey, P.I., MartinoSaltzman, D., Preedy, J.R. (1987a), Long-term efect of a first pregnancy on the secretion of prolactin. $N$. Engl. J. Med., 316, 229-234.

Musey, V.C., Collins, D.C., Brogan, D.R., Santos, V.R., Musey, P.I., Martino-Saltzman, D., Preedy, J.R. (1987b), Long-term effects of a first pregnancy on the hormonal environment: estrogens and androgen. $J$. Clin. Endocrinol. Metab., 64, 111-118.

Nasello, A.G., Sassatani, A.S., Ferreira, F.S., Felicio, L.F., Tieppo, C.A. (2003), Modulation by sudden darkness of apomorphine-induced behavioral responses. Physiol. Behav., 78, 521-528.

Parra-Bracamonte, G.M.; Magana, J.G.; Delgado, R.; Osorio-Arce, M.M.; Segura-Correa, J.C. (2005), Genetic and non-genetic effects on productive and reproductive traits in cows in dual-purpose herds in southeastern Mexico. Genet. Mol. Res., 4, 482-490.

Santos, J.M.G.; Moreira, I.; Martins, E.N. (2006), Lysine and metabolyzable energy requirements of lactating sows for subsequent reproductive performance Braz. Arch. Biol. Tech, 49, 575-581.

Schultz, W., Dayan, P., Montague, P.R. (1997), A neural substrate of prediction and reward. Science, 275, 1593-1599.

Schwarz, A.; Hosomi, R.Z.; Florio, J.C.; Bernardi,M.M.; Gorniak, S.L.; Spinosa, H.S. (2007), Rats offspring exposed to Ipomoea carnea and handling during gestation: neurochemical evaluation. Braz. Arch. Biol. Tech., 50, 425-433.

Schwarz, A.; Soares, M.R..; Florio, J.C.; Bernardi,M.M.; Spinosa, H.S. (2005), Rats exposed to Solanum lycocarpum fruti in utero during lactation: neurochemical, behavioral and histopathological effects. Neurotoxicol. Teratol. 27, 861-870

Xerri, C.; Stern, J.M.; Merzenich, M.M. (1994), Alteration of the cortical representation of the rat ventrum by nursing behavior. J Neurosci, 14, 17101721.

Sider, L.H., Hucke, E.E., Florio, J.C., Felicio, L.F. (2003), Influence of time of day on hypothalamic monoaminergic activity in early pregnancy: effect of a previous reproductive experience. Psychoneuroendocrinology, 28, 195-206.

Soriano Castrejon, A.; Vicente, A.M.G.; Romera, M.C.; Cano, J.V.; Marina, S.R.; Garcia, V.M.P.; Solis, S.R.; Rubio, M.P.T. (2005), 123-I Ioflupane (Datscan®) presynaptic nigrostriatal imaging in patients with movement disorders. Braz. J. Biol. Tech., 48, 115125.

Received: March 23, 2008; Revised: February 19, 2009; Accepted: August 25, 2009. 